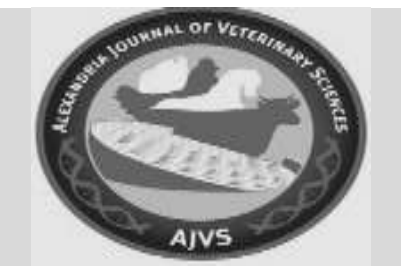

\title{
Using Double Dose of GnRH for Reducing Incidence of Cystic Ovaries in Cows
}

\author{
Noseir W.MB., Metwally K.K., and Negm, N.S. \\ Department of Theriogenology, Faculty of Veterinary Medicine, \\ Alexandria University, Egypt
}

\begin{abstract}
Key words: $\mathrm{GnRH}$

Cystic

Ovaries

Cows

\section{ABSTRACT:}

Cystic ovarian disease (COD) has been recognized as one of most important problem in dairy farm, it is a managerial and financial problem.120 Holstein cows with average age between 3 to 5 years were used in this study to determine whether giving $\mathrm{GnRH}$ at $14^{\text {th }}$ day and $21^{\text {st }}$ day after parturition (using two different types of $\mathrm{GnRH}$ ) has a role in decreasing incidence of cystic ovaries during days open, and is there is any effects of this program on fertility parameters (the interval from calving to conception, number of service per conception, first service conception rate). Also we refered to the season of milking to see how it affects on the incidence of COD. The findings of this study indicate that using two dose of GnRH (Receptal or Cystorlin) at 14 and 21 days after parturition did not give significant difference comparing with the costs of the programs in preventing COD except a moderate result by using Cystrolin especially with cow more than one season which decreased the incidence by $11 \%$. COD may reach to $42 \%$ in herd especially the high yielding Holstein cow. No significant effect on fertility parameters positively or negatively by using GnRH in postpartum period.
\end{abstract}

\section{INTRODUCTION}

One of the most common ovarian dysfunctions during the postpartum period is the formation of a cyst after ovulation failure (Laporte et al., 1994, Opsomer et al., 1998). In cattle, cystic ovarian follicles are generally defined as large $(>2.5 \mathrm{~cm}$ ) anovulatory follicles that persist on the ovary for at least 10 days in the absence of a corpus luteum. Despite the condition of persistence for 10 days or more, cysts are however frequently replaced by new ones (Hamilton et al., 1995). Cysts most commonly occur during the first 60 to 90 days postpartum ( Laporte et al., 1994).

Cystic ovarian disease (COD) has been recognized as a one of most important problem in dairy farm, it is a managerial and financial problem. There has been a considerable amount of research 
published on the disease. In spite of this large body of literature, the etiology of COD is not entirely understood. In addition, preventive management is not yet perfected. Fortunately, knowledge base of COD has increasedover the past thirty years. Much of the knowledge has been gained due to the advent of better technology (Cynthia, 2004).

There are three types of cysts occurring on the bovine ovary: follicular cysts, luteal cysts and cystic corpora lutea. Follicular and luteal cysts are the only two true types of cysts that are associated with an abnormal condition in cows. Cystic CL was considered nonpathological (Garverick, 1999).

$\mathrm{GnRH}$ is the most common treatment for COD. Treatment results in an immediate increase in $\mathrm{LH}$ secretion and luteinization of the cyst. Ovulation of the cows with follicular cysts responding to the second PGF2 $\alpha$ treatment when compared to $\mathrm{GnRH}$ alone(Lopez-Gatius et al. 2002). Because differentiation between luteal andfollicular cysts is difficult, and because PGF2 $\alpha$ treatment may be beneficial when treating follicular cysts, combining PGF $2 a$ with the $\mathrm{GnRH}$ treatment was recommended (Leonardo and colin 2004).

The objective of this study was to determine the effectiveness of two types of intramuscular injection of $\mathrm{GnRH}$ (Receptal and Cystrolin) and their preventive role in postpartum ovarian cysts

Under field study.

\section{Materials and Methods:}

2.1. Animals: The animals used in this study belonging to a private dairy farm in Borg el Arab (El-Gadid), Alexandria. 120 Holstein cows with average age between 3 to 5 years, animals housed in free open yards with metal shads and metal fence, each head have a free space about 30 meter square, with a sandy land. The cows were divided according to the production level, first category is the high lactating cows, which divided into three groups, the first one the average daily yield $40-55 \mathrm{~kg}$, the second group with an average daily yield $30-40 \mathrm{~kg}$. The last group with an average milk yield 20-30 $\mathrm{kg}$. The second group is the low lactating cows average daily yield about $10-20 \mathrm{~kg}$. The average production of the cows in the season were 8-11 tons according to the season of the milking of cows. Milking was automatic and performed three times daily.

Cows were routinely vaccinated. They were fed three times daily with a total mixed ration (TMR) after each milking, with well balanced ration, energy, protein, minerals and vitamins with special attention to trace element and selenium and phosphorus. All sources used were with high quality ration consisting of corn silage, hay and concentrates that consist of yellow corn, soya bean meal, bran, vitamins and minerals. Feed is open to all high lactating cows, and yards have a clean source of water.

Gynaecological examination of cows was conducted in the herd in 5-7 day intervals, first examination was at about 10- 15 days after parturition to investigate uterine involution and checking the health status of uterus and cervix. Second examination was at about 20-30 days to check for complete involution and examining the ovaries, after that near day 35 postpartum, the ovaries were checked for estrus at the day 40 for an early $\mathrm{Al}$ for a chance in decreasing days open.

Diagnosis wasdone by rectal palpation and clinical signs, the criteria used on palpation perrectum were the presence of multiple follicles on theovary with at leastone follicle being $>17 \mathrm{~mm}$ indiameter, the absence of a corpus luteum (CL) on either ovaies, and the lack of tonicity of the uterus. Cows were examined at days 25 and 35 postpartum, and at day 45 after Al. Animals which return to estrus less than 17 day or repeat breeder animals which take more than 3 
$\mathrm{Al}$ and get in estrus again were examined for normal cyclicty of ovaries and absence of any problems. Cystic animals were grouped according to the drug used and interval of treatment.

The objective of this study was to determine whether giving $\mathrm{GnRH}$ at $14^{\text {th }}$ day and $21^{\text {st }}$ day after parturition (using two different types of $\mathrm{GnRH}$ ) has a role in decreasing incidence of cystic ovaries during days open, and is there is any effects of this program on fertility parameters, (the interval from calving to conception, number of service per conception, first service conception rate,). Also we refered to the season of milking to see how it affects in the incidence of COD.

All cows were divided to two groups each one includes three subgroups as follows: Group (A) contained cows in the first season of milking, which were divided into; Group (A1) $(n=16)$, cows were treated with two dose of Receptal (buserlien acetate) $5 \mathrm{ml}$, at $14^{\text {th }}$ and 21 day after parturition. Group (A2) $(n=12)$ cows were treated with two dose of Cystrolin $2 \mathrm{ml}$ (Gonadorelin diacetate tytrahydrate), at $14^{\text {th }}$ and 21 day after parturition. Group (A3) $(n=16)$ control cows, without any hormonal treatment. Group (B) contained cows more than one season, which were divided into; Group (B1) $(n=31)$ cows were treated with double dose of Receptal $200 \mathrm{mg}$, at $14^{\text {th }}$ and 21 day after parturition. Group (B2) $(n=14)$, cows were treated with double dose of Cystrolin $100 \mathrm{mg}$, at $14^{\text {th }}$ and 21 day after parturition. Group (B3) $(n=30)$ control cows without any hormonal treatment.

All groups were regularly examined at 15 , 25 and 35 days after parturition. All changes were carefully recorded including changes in the ovaries, and health status of uterus and ovaries.

\section{RESULTS}

Table (1) represents percentage of COD incidence in cows in $1^{\text {st }}$ season $(37.5 \%$, $35 \%, 37.5 \%, A 1, A 2, A 3$, respectively). While cows more than one season were represented in table (2), giving highest incidence of COD in control group (B3) $46.6 \%$, and group (B1) and group (B2) which treated with $\mathrm{GnRH}$ (Receptal and Cystrolin), 38.7\%, 35.7\% ,on the other hand when we look to percentage all over the herd with no regarding to the season we found that in table (3) cows which treated with Receptal at 14 day and 21 day post partum, the incidence of COD is $38 \%$ while the incidence of COD in cows treated with Cystrolin is $33 \%$ and the percentage of incidence in control animals is $42 \%$.

The fertility parameters were represented in table (5) showing the conception rate in first service in the three groups $(36 \%$, $34.6 \%, 34.7 \%$ ).

Table 1. Cows in first season of milking

\begin{tabular}{llll}
\hline Drug used & $\begin{array}{l}\text { Number } \\
\text { of cows in } \\
\text { groups }\end{array}$ & $\begin{array}{l}\text { COD } \\
\text { cows }\end{array}$ & $\begin{array}{l}\text { Percentage } \\
\text { of incidence }\end{array}$ \\
\hline $\begin{array}{l}\text { Receptal } \\
\text { (A1) }\end{array}$ & 16 & 6 & $37.5 \%$ \\
$\begin{array}{l}\text { Cystorlin } \\
\text { (A2) }\end{array}$ & 12 & 4 & $33 \%$ \\
$\begin{array}{l}\text { No drug used } \\
\text { (control) (A3) }\end{array}$ & 16 & 6 & $37.5 \%$ \\
\hline
\end{tabular}


Table 2. cows more than one season.

\begin{tabular}{llll}
\hline Drug used & $\begin{array}{l}\text { Number of } \\
\text { cows in } \\
\text { groups }\end{array}$ & $\begin{array}{l}\text { COD } \\
\text { cows }\end{array}$ & $\begin{array}{l}\text { Percentage } \\
\text { of incidence }\end{array}$ \\
\hline $\begin{array}{l}\text { Receptal } \\
\text { (B1) }\end{array}$ & 31 & 12 & $38.7 \%$ \\
$\begin{array}{l}\text { Cystorlin } \\
\text { (B2) }\end{array}$ & 14 & 5 & $35.7 \%$ \\
$\begin{array}{l}\text { No drug used } \\
\text { (control) (B3) }\end{array}$ & 30 & 14 & $46.6 \%$ \\
\hline
\end{tabular}

Table 3. cows without regarding to the season.

\begin{tabular}{llll}
\hline Drug used & $\begin{array}{l}\text { Number of } \\
\text { cows in } \\
\text { groups }\end{array}$ & $\begin{array}{l}\text { COD } \\
\text { cows }\end{array}$ & $\begin{array}{l}\text { Percentage } \\
\text { of incidence }\end{array}$ \\
\hline $\begin{array}{l}\text { Receptal } \\
\text { (C1) }\end{array}$ & 47 & 18 & $38 \%$ \\
$\begin{array}{l}\text { Cystorlin } \\
\text { (C2) }\end{array}$ & 26 & 9 & $33.3 \%$ \\
$\begin{array}{l}\text { No drug used } \\
\text { (control) (C3) }\end{array}$ & 46 & 20 & $42 \%$ \\
\hline
\end{tabular}

Table 4.Fertility parameters in the three groups.

\begin{tabular}{lllll}
\hline & $\begin{array}{l}\text { Number } \\
\text { of cows } \\
\text { in group }\end{array}$ & $\begin{array}{l}\text { Number of } \\
\text { service for } \\
\text { the group }\end{array}$ & $\begin{array}{l}\text { Number of cows } \\
\text { concepted from } \\
1^{\text {st }} \text { service }\end{array}$ & $\begin{array}{l}\text { days to } \\
1^{\text {st }} \\
\text { service }\end{array}$ \\
\hline $\begin{array}{l}\text { Receptal } \\
200 \mathrm{mg}\end{array}$ & 47 & 107 & 17 & 66 \\
$\begin{array}{l}\text { Cystorlin } \\
\begin{array}{l}100 \mathrm{mg} \\
\text { No drug used } \\
\text { (control) }\end{array}\end{array}$ & 26 & 57 & 9 & 65 \\
\hline
\end{tabular}

Table 5. Fertility parameters in the three groups.

\begin{tabular}{lllll}
\hline & Days open & $\begin{array}{l}\text { First service } \\
\text { conception rate }\end{array}$ & $\begin{array}{l}\text { Over all } \\
\text { conception rate }\end{array}$ & $\begin{array}{l}\text { Service per } \\
\text { conception }\end{array}$ \\
\hline $\begin{array}{l}\text { Receptal } \\
\text { 200mg (C1) }\end{array}$ & 104 & $36 \%$ & $43.9 \%$ & 2.2 \\
$\begin{array}{l}\text { Cystorlin } \\
100 m g \text { (C2) }\end{array}$ & 106 & $34.6 \%$ & $45.6 \%$ & 2.2 \\
$\begin{array}{l}\text { No drug used } \\
\text { (control) (C3) }\end{array}$ & 105 & $34.7 \%$ & $45.5 \%$ & 2.2 \\
\hline
\end{tabular}




\section{Discussion:}

An ovarian cyst is an anovulated follicle-like structure (greater than $2 \mathrm{~cm}$ in diameter) that may persist on the ovary (usually for more than 10 days) or may regress to be replaced by other cysts (Peter, 1988). Also kesler et al. (1980) reported that cysts may regress andnew follicular structures may form into other anovulatory cysts. In some cases, cysts may persist for 40 days andadditional follicles may accompany to these persistent structures (Hamilton et al., 1980). In this case the cystic structure was diagnosed at the time of rectal palpation. Two types of pathologic cysts are recognized, follicular and luteal. Follicular cysts may be single or multiple involving one or both ovaries and are usually thin-walled. Luteal cysts are usually single structures on one ovary and generally are thicker-walled than follicular cysts. Follicular cysts can progress to become luteal cysts through the luteinization process (Augustine and Peter,2000).

Gonadotropin-releasing hormone $(\mathrm{GnRH})$ has been used in the postpartum period, however, the studies have yielded mixed results. Results show little or no positive impact on the subsequent fertility of treated cows (Gaines, 1994). Herds with good reproductive performance showed a benefit from routine treatment with $\mathrm{GnRH}$ but in herds with poor reproductive performance little effect was noted (Nash, et al, 1980). Archbald, et al., in 1990 said that Treatment on day 23 in cows without a corpus luteumreduced days open by 26 days. Treatment on day 15 may help cows that are free from puerperal infections (Peter and Bosu, 1988). GnRH given 13 to 14 days postpartum helped cows undergoing slow involution of the reproductive system with no other clinical problems (Foote and Rick, 1999). It may also reduce the number of days to first estrus without altering reproductive performance (Beckett and Lean, 1997).
On the other hand Etherington et al. 1983 said that, treatment with $\mathrm{GnRH}$ on day 15 postpartum resulted in a significant increase in the subsequent incidence of pyometra and prebreeding anestrous.

In this study, no remarkable differences in fertility parameters between cows treated with $\mathrm{GnRH}$ (Receptal or Cystrolin) and with not treated cows, in the other way we found a small effect from $\mathrm{GnRH}$ especially Cystrolin in preventing the incidence of COD especially in cows more than one season. In this point Britt et al, in 1977 stated that GnRHhas also been used prophylactically to reduce the incidence of ovarian cysts. Administering the hormone 8 to 23 days and 12 to 14 days (Zaeid et al, 1980) after calving was found to reduce the number of cows that developed ovarian cysts or were culled for infertility.

When we compare the incidence of COD between the animals in $1^{\text {st }}$ season and animals more than one season (control groups), (A3 and B3), (37.5\% and $46.6 \%$, we will find a remarkable difference between them, and this percentage indicates the effect of age on the incidence of COD, so in the point of parity we agreed with peter (1997) when he talked about the effect of parity on the incidence of COD, also a Norwegian research by (Nelson et al.,2010) stated that cows in higher parity have an increased risk of being diagnosed with COD.

We obtain a general percentage all over the herd $42 \%$ we can imagine it is not true percentage but now days with rapid development of genetic and high selection to sire give more milk and the huge amount of milk which act as big stress factor on the animal, it is a normal percentage. Allrich(2001) have concluded that ovarian cysts reduce reproductive efficiency on almost every dairy farm in the United States. It has been estimated that the incidence of ovarian cysts ranges from 5 to 20 percent in most herds. A recent Wisconsin field 
study of dairy herds reported that the incidence of ovarian cysts ranged from a low of 16.2 to a high of 47.4 percent. Mature cows have a higher incidence (39 percent) of ovarian cysts than do first-calf heifers (11 percent). Risk of COD increased with increased herd milk yield in the previous or current lactation (Gröhn et al., 1990). The expected probability of COD appearance in third lactation cows was 3.1 times higher in a cow producing $12,000 \mathrm{~kg}$ (305-day milk yield) than a cow producing $6,000 \mathrm{~kg}$ (Fleischer et al., 2001). When we have a look in our animal in the study we found their milk production about 8 tons for the first season and more than 10 tons in next seasons.

When we come back to the effect of $\mathrm{GnRH}$ as a preventive to COD and its importance in fertility parameters in the other field trial we will find Britt (1977) nearly agreed with us, when he made the first published field trial was conducted using 204 Holstein Friesiancows in four privately owned Michigan dairy herds. During one of the biweekly herd visits, each cow was given either saline solution or $200 \mathrm{MgGnRH}$ between 8 and 23 dayspostpartum partum. The mean time of treatment was $14.8 \pm 0.4$ days postpartum. The incidence of ovarian follicular cysts, reasons for disposal and reproductive performance were determined. The frequency of ovarian cysts was significantly greater in saline-treated controls compared to $\mathrm{GnRH}$-treated cows, $15.3 \%$ versus $5.7 \%$, respectively. Measures of reproductive performance were not significantly different between GnRH-treated and control cows.

In conclusion, the findings of this study suggest that using two dose of $\mathrm{GnRH}$ (Receptal or Cystorlin), at 14 and 21 days after parturition did not give a significant difference comparing with the costs of the programs in preventing COD except a moderate result by using Cystrolin especially with cow more than one season which decreased the incidence by
$11 \%$. COD may reach to $42 \%$ in herd especially the high yielding Holstein cow. No significant effect on fertility parameters positively or negatively by using $\mathrm{GnRH}$ in postpartum period.

\section{REFERENCES}

Augustine and Peter, Advances in Dairy Technology 2000. Volume 12, Managing Postpartum Health and Cystic Ovarian Disease Department of Veterinary Clinical Sciences, School of Veterinary Medicine, Purdue University, West Lafayette, IN 47907

Britt $\mathrm{J} \mathrm{H}$. Harrison D S and Morrow D A. 1977. Frequency of ovarian follicular cysts, reasons for culling, and fertility in Holstein-Friesian cows given gonadotrophin-releasing hormone at two weeks after parturition. American Journal of Veterinary Research 38: 749.

Cynthia j. Johnson, m.s. 2004. cystic ovarian disease in cattle on dairies in central and western Ohio ultrasonic, hormonal, histological, and metabolic assessments.

Etherington, W.G. W.T.K. Bosu, S.W. Martin, J.F. Cote, P.A. Doig and K.E. Leslie 1983. Reproductive Performance in Dairy Cows Following Postpartum Treatment with Gonadotrophin Releasing Hormone and/ or Prostaglandin.

Fleischer, P., M. Metzner, M. Beyerbach, M. Hoedemaker, W. Klee 2001. TheRelationship Between Milk Yield and the Incidence of Some Diseases in Dairy Cows. J.Dairy Sci. 84: 2025-2035.

Gaines J. 1994. The use of gonadotropin releasing hormone andprostaglandin for programmed breeding of dairy cattle. ProcSoc forTheriogenol. 109-119.

Garverick, H. A. 1999. Ovarian Follicular Dynamics and Endocrine Profiles in Cows With Ovarian Follicular Cysts. In: J. L. Howard R. A. Smith (Eds.) Current Veterinary Therapy 4: Food Animal Practice. pp. 577-580.

Grohn Y, Erb HN, McCulloch CE, Saloniemi HS. Epidemiology of 
reproductive disorders in dairy cattle: Associations among host characteristics, disease and production. Prev Vet Med. 1990; 8(1):25-39.

Hamilton SA, HA Garverick, DH Keisler, $\mathrm{ZZ} \mathrm{Xu,} \mathrm{K} \mathrm{Loos,} \mathrm{RS} \mathrm{Younquistand} \mathrm{BE}$ Salfen, 1995.Characterization of ovarian follicular cysts and associated endocrine profiles in dairy cows. BiolReprod, 53:890-898.

Kesler DJ, HA Garverick, AB Caudle, RG Elmore, RS Youngquist and $J$ Bierschwal, $1980 . \quad$ Reproductive hormone and ovarian changes incows with ovarian cysts. J Dairy Sci, 63: 166170.

Kesler, D. J. and H. A. Garverick. 1982. Ovarian cysts in dairy cattle: a review. J. Anim. Sci. 55:1147-1159.

Laporte HM, Hogeveen H, Schukken YH, Noordhuizen JPTM, 1994. Cystic ovarian disease in Dutch dairy cattle I. Incidence, risk factors and consequences. Livest Prod Sci38, 191197

Leonardo Brito, colin 2004. cystic ovarian disease in cattle US Production Laboratory Manager at ABS Global.

Nash, J.G., L. Ball and J.D. Olson 1980. Effects onreproductive performance of administration of $\mathrm{GnRH}$ to early postpartum dairycows. J. Anim. Sci. 50: 1017-1021. 1980.
Nelson T., Adam D Martin, Olav osteras, Nelson et al. ActaVeterinaria Scandinavica 2010. Risk factors associated with cystic ovarian disease in Norwegian dairy cattle Norwegian School of Veterinary Science, Oslo, Norway Department of Production Animal

Opsomer G, Coryn M, Deluyker H, de Kruif A, 1998. An analysis of ovarian dysfunctionin high yielding dairy cows after calving based on progesterone profiles. Reprod Domest Anim 33, 193204

Peter A.T., Bosu W.T.K. 1988. Influence of intrauterine infections and follicular development on the response of $\mathrm{GnRH}$ administration inpostpartum dairy cows. Theriogenol. 29:1163-1175.

Roberts SJ, 1986. Infertility in the cow. In: Veterinary Obstetrics and Genital Diseases:Theriogenology. 3rd ed., Vermont: Woodstock; pp 421-433

Youngquist, R. S. 1986: Cystic Follicular Degeneration in the Cow. In: D. A. Morrow (Ed.) Current Therapy in Theriogenology. pp. 243-246. W.B. Saunders Co., Philadelphia.

Zaeid A A, Garverick H A, Bierschwal C J. Elmore G. Youngquist R $S$ and Sharp A J. 1980. Effect of ovarian activity and endogenous reproductive hormones on GnRH-induced ovarian cycles in postpartum dairy cows. Journal of Animal Science 50: 508-513. 